\title{
İsmet Özel'de dünya sistemi, sistemin geleceği ve Türkler
}

\section{Engin ÇAĞMAN 1}

\begin{abstract}
APA: Çağman, E. (2020). -İsmet Özel'de dünya sistemi, sistemin geleceği ve Türkler. RumeliDE Dil ve Edebiyat Araşturmaları Dergisi, (18), 190-205. DOI: 10.29000/rumelide.705573.
\end{abstract}

\section{$\ddot{\mathbf{O z}}$}

1960'lı yıllardan itibaren dünya gündemine gelen ve akademik çevrelerde tartışma konusu olan "Dünya Sistemi” kavramının Türkiye'de yaygınlaşmasında şair, yazar ve düşünce adamı İsmet Özel’in önemli rolü vardır. Özel, muhtelif eserlerinde, gerek dünya ve Türkiye tarihi analizlerinde, gerek güncel olayların yorumunda kavrama sıklıkla atıfta bulunmuştur. İsmet Özel 14. yüzyılda İtalyan şehir devletlerinde temelleri atılan dünya sisteminin daha sonra kuzey Avrupa'ya yönelerek kendisine mahsus bir hayat tarzı ortaya koyduğunu ve tüm geleneksel yapıları dönüştürerek yayılma gösterdiğini ifade eder. Özel'e göre geleneksel insan-toplum-devlet ilişkilerinin yerine sermayeyi ve buna bağlı ilişkileri ikame eden dünya sisteminin ortaya çıkışı doğrudan Türklerle ilişkilidir. Türklerin Avrupa'yı çevreleyerek sıkıştırması sonucunda yeni iktisadi yöntemler aramak zorunda kalan Avrupa, sonuçta tarihte daha önce görülmemiş olan yeni ve eşsiz bir iktisadi düzen ortaya çıkarmıştır. İsmet Özel'e göre sistem, dünya savaşlarından her defasında galip çıkmasına ve kendisini yenilemesine rağmen varlığı ve geleceği açısından bazı riskleri de barındırmaktadır. Özellikle Müslümanlar ve Türkler sistem için bir tehdit teşkil etmektedir. Her ne kadar mevcut durumda bu tehdit somut olarak görülmese de dünya sistemi karşıtlı̆̆ İslam dininin kendisinde potansiyel olarak mündemiçtir. Dolayısıyla bu karşıtlığı harekete geçirmek Müslümanların zihin ve eylemleriyle kendisini gösterebilmesine bağlıdır. Benzer bir durum Türkler için de geçerlidir. İsmet Özel'e göre tarihte hiçbir zaman kapitalist olmamış hatta anti-kapitalist bir yönetim ve toplum düzeni tesis etmiş olan Türklük, tarihten gelen özellikleriyle dünya sistemiyle baş etmede imkânlar sunmaktadır.

Anahtar kelimeler: İsmet Özel, Immanuel Wallerstein, dünya sistemi, Kapitalizm, Türkler.

\section{World system, its future and Turks according to İsmet Özel}

\begin{abstract}
Figuring on the agenda of the world and academic debates since the 1960s, the concept of "World System" also gained popularity in Turkey, owing much to the influence of İsmet Özel, a poet, writer and thinker. In his several works he frequently referred to the concept not only when analyzing world and Turkish history but also interpreting current events. Özel asserts that, with its origins going back to the Italian city-states of the $14^{\text {th }}$ century, the world system later shifted its center of gravity to northern Europe, and subsequently created a distinct way of life, and spread around the globe by transforming all traditional formations and structures. In his view, it is Turks who have to do directly with the emergence of the world system, which replaced the traditional man-society-state relations with capital and relations involving capital. As Turks encircled and pressed into Europe, Europe was forced to seek for new economic methods, which eventually paved the way for an unprecedented and unique economic order. İsmet Özel believes that, although it emerges victorious out of every world
\end{abstract}

1 Dr. Öğr. Üyesi, Bandırma Onyedi Eylül Üniversitesi, İktisadi ve İdari Bilimler Fakültesi, İktisat Bölümü (Balıkesir, Türkiye), ecagman@bandirma.edu.tr, ORCID ID: 0000-0002-4733-8418 [Makale kayıt tarihi: 31.01.2020-kabul tarihi: 20.03.2020; DOI: 10.2900o/rumelide.705573] 


\begin{abstract}
war and succeeds in adapting itself, it also inherently contains certain risks as regards to its own existence and future. Muslims and Turks in particular pose a threat to the system. Although such threat is not plausibly concrete at present, the anti-world system stance potentially inheres in Islam. Thus, the capacity to activate this resistance depends on the efforts of Muslims to assert themselves through ideas and actions. This also holds true for Turks. In his view, Turkishness never capitalists in their history and even established an anti-capitalist system of government and society instead, a historically-inherited quality which provides them with many potentials for coping with the world system.
\end{abstract}

Keywords: İsmet Özel, Immanuel Wallerstein, world economic system, Capitalism, Turks.

\title{
1. Giriş
}

Dünya sistemi kavramı, Türk şair, yazar ve düşünce adamı İsmet Özel’in yazılarında çok önemli bir yer tutar. Doğrudan konuyla ilgili müstakil bir eseri olmamakla birlikte İsmet Özel, dünya sistemine (ve kapitalizme) eserlerinin muhtelif yerlerinde değinmekte; sistemin tarihçesine, günümüzde aldı̆̆ biçim ve muhtevasına, tarihi süreçte sistem karşısında Türklerin konumuna ve günümüz Türkiye'sine dair görüşlerini ortaya koymaktadır.

Kavramı sıklıkla kullanan ve akademik çevrelere yayılmasında önemli rol oynayan İmmanuel Wallerstein'a göre içinde yaşadığımız yerküreye hükümran olan dünya sisteminin kökenleri 16. yüzyıla kadar gitmektedir. Avrupa ve Amerika kıtasının bazı bölgelerinde konumlanarak zamanla tüm dünyayı kapsayacak şekilde genişleyen sistem, geçmişten günümüze her zaman bir dünya-ekonomi olarak varlığını sürdürmektedir. (Wallerstein, 2004, 45-46)

İsmet Özel'e göre temelleri 14. yüzyılda İtalyan şehir devletlerinde atılmış olan dünya sistemi, daha sonra kuzeye yönelmiş ve Amsterdam-Paris-Londra ekseninde şekillenerek yeryüzünde hakimiyet kurmuştur. (Özel, 2012, 121) Sistem, kendi oluşum sürecinde Yahudilik ve Hristiyanlık da dahil olmak üzere tüm geleneksel dinleri kendisine hizmet edecek şekilde yeniden tanımlamayıp yorumlayarak gücünü koruyabilmiştir. Fakat sadece İslam dini, sahih karakterini muhafaza ettiği için sistemle uzlaşmazlığını devam ettirebilmiştir. (Özel, 1991, 162-163) Tarihte bu derecede kırılmaya neden olan dünya sistemini İsmet Özel "kendi dini vasıflarını gözden uzak tutmaya çalışan batıl bir din" olarak nitelendirmektedir. Bu nedenle salt iktisadi, siyasi veya sosyal mekanizmalardan biri olduğu gerçeğinden yola çıkarak sistemin anlaşılamayacağını ve alt edilemeyeceğini ileri sürer. (Özel, 1991, 8284)

Çalışma, eserleri üzerinden İsmet Özel’in kapitalist dünya sistemine yaklaşımını ele almaktadır. Önce terimin yaygın olarak kullanımında çok önemli rolü olan Immanuel Wallerstein'in dünya sistemi, hegemonik bir güç olarak Amerika Birleşik Devletleri ve sistemin geleceğiyle ilgili düşünceleri kısaca özetlenmeye çalışılmıştır. Ardından bir dünya sistemi olarak kapitalizmin zuhuru ve yayılması, daha sonra sistemin işleyişi, tarihten günümüze sistemle Türklerin ilişkisi ve nihayetinde sistemin güçlü ve zayıf yönleri Özel’in eserleri ekseninde ortaya koyulmaya çalışılmıştır. Böylece günümüz dünyasında meydana gelen ekonomik ve siyasi olayların analizinde sıklıkla kullanılan dünya sistemi kavramının anlaşılmasına katkı sunulması hedeflenmiştir. 


\title{
2. Wallerstein ve dünya sistemi
}

\subsection{Sistemin özellikleri}

Modern dünya sisteminin kökenleri, zuhuru Yeniçağların başlarına kadar giden kapitalizme dayanır. Tarihsel ve toplumsal bir sistem olan kapitalizmin ayırt edici özelliği sermayenin çok özel bir yolla kullanıma/yatırıma girmesidir. Sistemde temel amaç sermayenin sürekli olarak kendisini büyütmesi ve kapitalistin, sahip olduğu sermayeyi biriktirme hedefine ulaşmak için insanlarla kurmak zorunda olduğu ilişkilerdir. (Wallerstein, 2006, 12)

Sanayileşme Devrimi ve işçi sınıfının ortaya çıkmasıyla birlikte artan üretimin pazarlanması, hem dağıtım sisteminin ve hem de alıcı gruplarının ortaya çıkmasını sağladı. Bunun neticesinde çevre, yarı çevre ve merkez ülkeler teşekkül etti. "Bu sistem böylesi üçlü bir yapılanma içersinde sadece değiş-tokuş süreçlerinde değil, üretim, dağıtım ve yatırım süreçlerinde de ciddi bir 'metalaştırma' yöntemine gitmiştir. Ancak bu toplumsal süreçlerin metalaştırılması da yeterli olmayıp, üretim süreçleri de bir meta zinciri halinde birbirine bağlanmıştır.” (Oktik-Kökalan, 2001, 124)

Sermayenin kesintisiz birikiminden güç aldığı için kapitalist özellikte olan ve eşitsiz mübadele üzerine kurulan düzen 19. yüzyllın sonunda tüm dünyaya yayılmıştır. Bir yandan burjuvazi işçilerin artık değerine el koyarken öte yandan çevre (periferi) ülkelerin artık değeri de merkez ülkelere aktarılmaktadır. (Wallerstein ve Diğerleri, 1984, 11-12)

\begin{abstract}
"Modern dünya sisteminin kapitalist dünya ekonomisinin gerçekliği, hiyerarşik, eşitsiz, kutuplaştırıcı bir sistem olmasıdır; siyasi yapısı da bazı devletlerin öbürlerinden bariz biçimde daha güçlü olduğu bir devletlerarası sisteme dayanır. Sonsuz sermaye birikimi sürecine yardım babından, daha güçlü devletler sürekli olarak daha zayıf devletlere, kendi iradelerini mümkün olduğu ölçüde dayatırlar. Buna emperyalizm denir ve dünya sisteminin yapısına içkin bir şeydir.” (Wallerstein, 2004, 119)
\end{abstract}

Doğası gereği kapitalist bir dünya ekonomide serbest pazardan söz edilemez. Böyle bir pazarın mevcut olması sermayenin sonsuz birikimini imkânsız kılardı. Haddi zatında kapitalizmin pazar olmadan işlemesi mümkün olmasa da kapitalistler tam anlamıyla serbest olarak işleyen pazarlardan ziyade kısmen serbest pazarlara ihtiyaç duyarlar. Tam anlamıyla serbest olarak işleyen pazarlarda fiyatlar ve dolayısıyla kârlar azami oranda düşeceği için bu durum, kapitalist sistemin temel toplumsal dayanaklarını ortadan kaldıracak ve üreticiler açısından cazibesini yitirecektir. $(2004,48)$

Modern dünya sisteminde bazı devletlerin hegemonik güç olarak ortaya çıtığı görülmektedir. "Bunlardan birincisi, 17. yüzyllın ortalarında günümüzde Hollanda olarak adlandırılan Birleşik Eyaletler'dir. İkincisi 19. yüzyılın ortalarında Birleşik Krallık, üçüncüsü ise 20. yüzyılın ortalarında Birleşik Devletler'dir." (Wallerstein, 2004, s.92) "Hegemonya bir tür istikrar yaratır ve kapitalist şirketler, özellikle öncü konumundaki tekelci öncü sanayiler bu istikrar içinde zenginleşir. Hegemonya sadece düzeni değil aynı zamanda herkes için daha müreffeh bir geleceği garanti ediyor göründüğü için sıradan insanlar arasında da geniş kabul görür.” (2004, s.93)

\subsection{Dünya savaşları ve Amerikan yüzyılı}

Wallerstein'e göre kapitalist dünya ekonomisi 20. yüzylldaki dünya savaşlardan önce iki defa daha dünya savaşının içine dahil edilmiştir. Bunlardan birincisi Habsburglarla Hollanda'yı karşı karşıya getiren 1618-1648 savaşı, ikincisi de 1792-1815'de Fransa-İngiltere arasında vuku bulan çatışmalardır. (Wallerstein, 1984, 41) Amerika Birleşik Devletleri II. Dünya Savaşı’ndan sonra kapitalist dünya 
sisteminin mutlak hegemonik gücü olarak ortaya çıkmış; fakat mücadele bir önceki yüzyılda başlamıştır. 19. yüzyılın hegemonik gücü olan ve 1870 'lerde düşüşe geçen Büyük Britanya'nın yerini almak üzere ABD ile Almanya arasında büyük bir rekabet söz konusu olmuştur. Wallerstein iki dünya savaşını, belirli fasılalarla gerçekleşen tek uzun dünya savaşı olarak nitelendirir. Savaşın mutlak galibi olan ABD'nin 1945'den sonra gerçek hegemonya dönemi başlamış ve bu süreç 1967/73 yllarına kadar sürmüştür. (Hopkins-Wallerstein, 2000, 19-20)

Savaş sonrasında ABD’nin karşılaştığı iki büyük problem, sahip olduğu ekonomik avantajları sürdürebilmesini sağlayacak istikrarlı bir dünya düzeninin kurulması ve savaş döneminde dünya genelinde azalmış olan efektif talebin canlandırılmasıydı. ABD, yeni bir istikrarlı düzen problemini bir yandan 1945-55 döneminde kendi kontrolünde ihdas edilen Birleşmiş Milletler, IMF ve Dünya Bankası gibi kurumlarla ve öte yandan SSCB ile anlaşma yaparak çözdü. Dünyada efektif talebin canlandırılması meselesini ise Batı Avrupa'ya Marshall Planı ve Japonya'ya bu plana eşdeğer olarak yaptığı ekonomik yardım sayesinde halletti. Ayrıca, yine kendi liderliğinde kurulan Kuzey Atlantik Paktı (NATO) ile siyasi ve askeri açıdan da yeni düzeni garanti altına aldı. (Wallerstein, 2003, 48-49)

Wallerstein, ABD’nin hegemonik gücünün 196o'lardan itibaren birbiri üzerine yükselen dört simgeyle ifade edilebilecek olayla aşınmaya başladığını ileri sürer. Bunlar, Wietnam savaşı, 1968 devrimleri, 1989 Berlin Duvarı'nın yıkılması ve 2001 Eylül'ndeki terörist saldırılardır. Netice olarak günümüzde ABD "gerçek güçten yoksun, yalnız bir süpergüç, kimsenin takip etmediği ve çok az kişinin saygı duyduğu bir dünya lideri ve kontrol edemediği küresel bir kaos içinde tehlikeli bir biçimde sürüklenen bir ülke haline geldi." $(2003,22)$

1960'larda ABD’nin gücüne vurulan en önemli darbe, Batı Avrupa ve Japonya ekonomilerinin toparlanarak verimlilikte ABD'yi yakalamaları ve kendi ulusal piyasalarında kontrolü sağlamalarıdır. Hatta bu bölgeler dünya ve ABD piyasalarında $\mathrm{ABD}$ ürünleriyle rekabet edebilir hale geldiler. 6o'ların sonlarında ABD ekonomik avantajlarını büyük ölçüde yitirdi. (Wallerstein, 2003, 50) 1990'dan 2025/2050'ye kadar olan dönemde çok büyük ihtimalle barış, istikrar ve meşruiyet sıkıntısı çekileceğini iddia eden Wallerstein, bunun kısmi nedenini hegemonik güç olan ABD’nin zayıflamasına bağlarken asıl nedenin dünya sistemindeki krizden kaynaklandığını iddia eder. (Wallerstein, 1998, 32)

\subsection{Dünya sistemine karşıt hareketler ve sistemin geleceği}

19. yüzyılın sonları ve 20. yüzyılda meydana gelen sistem karşıtı hareketler Wallerstein'e göre ortak bir zemin bulmada yetersiz kalmıştır. Her sistem karşıtı hareket daha çok kendi taraftarlarının mağduriyetlerine odaklanmış ve diğer mă̆duriyetlerin gündeme getirilmesine yeterince özen göstermemiştir. (Wallerstein, 2004, 109) 1968'den itibaren sistem karşıtı daha demokrat ve eşitlikçi hareketlerin ortaya çıktığını ileri süren Wallerstein bu bağlamda dört farklı türde girişimden söz eder. Bunlardan birincisi Maocu hareketler olmakla birlikte bu yönelimler kurucusunun ölümüyle birlikte etkinliğini yitirmiş ve önemi kalmamıştır. İkinci grubu teşkil eden yeşiller, çevreciler ve feministlerle birlikte ırksal ya da etnik azınlıkların bazı ülkelerde hala önemli olmayı sürdüren hareketleridir. Üçüncüsü, insan hakları örgütleridir. $\mathrm{Bu}$ örgütler devletlerin politikalarını insan haklarına yönlendirmekle birlikte zamanla muhalif olmaktan çıkmış ve devletlerin yardımcısı haline gelerek sistem karşıtı olmaktan uzaklaşmıştır. Dördüncüsü ise küreselleşme karşıtı örgütlerdir. (Wallerstein, 2003, 234-237) 
Wallerstein, 20. yüzylldaki sosyalist ülkelerin (Wallerstein kendisini sosyalist olarak adlandıran ülkelerin hiçbirinin sosyalist olmadığını düşünür.) ciddi bir sistem karşıtllğg oluşturmadığını ileri sürerek onların bağımsız tarihsel sistemler olmadığını, kapitalist dünya ekonomisinin değer yasasına bağımlı olduklarını, sistemin parçaları olmaya devam ettiğini ve devletlerarası sistemin sınırlamalarıyla bağlandıklarını iddia eder. (Wallerstein, 1984, 60)

Wallerstein son tahlilde, gelecekte sisteme karşı iki alternatif ortaya koymaktadır. Birincisi "bugünkü ve daha önceki çoğu sistemlerimizin olduğu gibi hiyerarşik, eşitsiz ve baskıcı bir sistem inşa edebiliriz. Alternatif olarak, görece eşitlikçi ve demokratik olan Fransız Devrimi’nin sloganını yerine getirecek bir sistem inşa edebiliriz." (Wallerstein, 1993, 297)

Wallerstein'e göre dünya ekonomisinin parçalanma sürecini içeren yeni bir döneme girilmiştir. $\mathrm{O}$, bu dönemde sistemi devam ettirme düşüncesinin aksine yeni bir dünya düzeni kurulmasının gerekliliğine ve bu nedenle de ideolojik bir perspektife ihtiyaç duyulduğuna inanır. Bunun için özne olarak eşitlikçi ve iç içe geçmiş çok sayıda grupların oluşturulmasını, ilave olarak grupların önceliğine dayalı siyasi bir programın teşkil edilmesini önerir. Böyle bir organizasyonun tek başına sistemi ortadan kaldırmada yeterli olmasa da siyasi açıdan ve ekonomik eşitsiz yapının kalkması için egemen güçler üzerinde baskı yaratacağını düşünür. Öte yandan Wallerstein, sistem ve sistemin işleyişindeki çatlakların ilk tezahürlerinin devlet yapılarının düzen sağlama konusundaki kabiliyetlerinin ortadan kalkmasıyla tebellür ettiğini iddia eder. Bunun sonucunda savunma ve ekonomik maliyetleri artış göstermekte ve güven ortamı gittikçe etkisini yitirmektedir. (Oktik-Kökalan, 2001, 129-130)

\begin{abstract}
“Wallerstein'e göre bugün içinde bulunduğumuz bu karmaşa ve kaos ortamından yeni bir düzen doğacaktır. Önümüzdeki yirmi beş-elli yıl bugünkünden farklı olacak olan, dünya pazarlarının işleyişinden çok, dünya siyasi ve kültürel yapılarının işleyişi olacaktır. devletler güvenliği sağlamada zorlanacak, dünya genelinde ortak egemen bir söylem olmayacak ve kültürel tartışma biçimleri bile tartışma konusu olacaktır. karışıklığın olması yine de belirgin, sınırlı hedeflere ulaşmaya çalışan muhalif grupların varlığını engellemeyecektir. Oan göre temel sorun, sistemin, demokrasisinin yokluğu anlamın agelen büyük eşitsizliklerin varolduğu fikridir.” (2001, 130-131)
\end{abstract}

\title{
3. İsmet Özel ve dünya sistemi
}

\subsection{Dünya sisteminin zuhuru ve yayılması}

İsmet Özel'e göre dünya sistemi kavramı 6o'lı yıllarda Batı Avrupa ve Kuzey Amerika'da yaygın olarak kullanılmaktaydı. Dünyadaki mevcut iktisadi, siyasi ve sosyal düzenin tartışma konusu olduğu bu dönemde yürürlükteki sistemi kınayan, bu sistemden kurtulmak isteyen ve yürürlükteki insani ilişkilerin dışında bir yön arayışından söz eden insanlar kavramı gündeme getirerek sorgulamaya başlamışlardır. (Özel, 1990, 95)

İsmet Özel, dünya sistemini şöyle tanımlar:

\begin{abstract}
"Gerçekten bugün karşımıza dünya sistemi diye çıkan düzen (karşımıza çıkmaktan ziyade bizi kuşatan, bizi içine hapseden düzen) malların ve değerlerin üretilmesi, dolaşımı, tüketilmesi sebebiyle yaşanan bir düzendir. Dünya sistemi belli bir üretim-dağıtım-tüketim zincirinin devamı için gerekli sosyal hayatı besleyip büyütür. Gerekli saydığı sosyal hayatın yaygınlaşmasına yarayan siyasi yapıyı kurar ve korur." (Özel, 1989, 77-78) "Sistemi ayakta tutan bir üretim tarzının ortaya çıkardığı piyasa mekanizması ve nihayet para hareketleri veya paranın yerini tutan ilişkiler zinciridir. Sistemin dayattığı sosyal ilişkiler vardır ve bu sosyal ilişkileri kaim kılmak üzere (daha doğrusu bu sosyal ilişkilerin bekçiliğini yapmak için) getirilen siyasi rejimler vardır. İnsanlar hayatlarının, sistemin işlemesine sıkı sıkıya bağlı olduğuna inandırılmışlardır.” (Özel, 1989, 79)
\end{abstract}


Yine Özel'e göre dünya sistemi, kısaca ifade etmek gerekirse beynelmilel siyasi ilişkileri denetim altında tutan mali üstünlüktür.

\begin{abstract}
"Sistemin çekirdeğini çeşitli unsurlar arasındaki mali bağımlılık teşkil eder. Bu çekirdeği korumak, yürürlükteki mali mecburiyetleri devam ettirebilmek için dünya sistemi imtiyazlı bölgeler oluşturur. Sistemin en imtiyazlı bir bölgesi vardır. Diğer bölgeler hiyerarşik bir sıralanmayla merkez çevresinde yer alırlar. Dünya sistemi kapitalizmle özdeş değildir. ${ }^{2}$ Çünkü kapitalizm her zaman mali oligarşi olarak karşımıza çıkmaz ve sermaye gücü her zaman mali hegemonyaya dayalı değildir. Sistem ilişkileri mütedavil sermaye ilişkileridir ve bu ilişkiler günden güne soyut karakter kazanmakta, karmaşık hale gelmektedir. Dünya sistemini Batı medeniyeti denilen ve daha çok bir zihniyeti ifade eden oluşumla da özdeş sayamayız. Dünya sistemi Batı medeniyetini de hegemonyasında tutan bir örgütlenme ve mali imtiyaz sahibi bir şirket-devlet karakterindedir.” (Özel, 1990, 97-98)
\end{abstract}

Kadim dönemlerde de var olan sermaye birikimiyle kapitalizmin aynı şeyler olmadığına dikkat çeken Özel, kapitalizm denilince Yeniçağların birikmiş ve merkezileşmiş sermayesi eliyle işleyen düzenin anlaşılması gerektiğine dikkat çeker. Sermayenin birikmesi ve belirli ellerde toplanması insanlık tarihinde çok daha önce de görülmüştür. Fakat bununla birlikte sermayenin her temerküz ve teraküm ettiği yerde kapitalizmin olduğu söylenemez. "Çünkü bir yerde kapitalizm var diyebilmemiz için o yerde toplumun çarkını birikmiş ve merkezileşmiş haliyle sermayenin çeviriyor olması lazımdır. Çarkı döndüren insanlar çark döndürme işini bir ücret karşllı̆̆ yaptıkları taktirde 'sermaye' belirleyicilik vasfını ele geçirebilir.” (Özel, 2004a, 81) Öte yandan Özel'e göre pazarın serbestçe işlemesiyle kapitalizmin aynı anlama geldiği gibi bir yanılsama da söz konusudur. Halbuki bir insanın kendi adına mal ve hizmet üretmesi ve bunların ticaretini yapması ile kapitalizm birbirinden farklı hususlardır. 3 Böyle bir algının doğmasında anti-komünizm ve soğuk savaş önemli rol oynamıştır. (2004a, 83)

İsmet Özel, kapitalizmin doğuşu ve dünya sisteminin ortaya çıkışıyla Türkler arasında doğrudan bir bağ kurmaktadır. Ona göre Türklerin Doğu Avrupa ile Kuzey Afrika'yı ele geçirmesi karşısında Batı Hristiyanlığı Türkler tarafından Avrupa'ya hapsedilmiş; Avrupalılar dünyanın daha üretken alanlarıyla kendi aralarında bilinen ve hayati önemi olan dünyadan yalıtılmıştır. Neticede Avrupa milletleri başlarının çaresine bakabilmek ve zenginleşmek için kendilerine mahsus yeni iktisadi usuller icat etmek ve etkinleştirmek zorunda kaldılar. Bunun için gereken şartlar öncelikle İtalyan şehir devletlerinde ortaya çlktı. Dünya sisteminin/kapitalizmin temelleri XIV. Yüzyıldan itibaren Venedik başta olmak üzere Ceneviz ve Floransa gibi şehir devletlerinde atıldı. Deniz aşırı ticaret sayesinde, İtalyan şehir devletlerinde hem hızlı bir şekilde artış gösteren hem de az sayıda kişinin elinde toplanan sermaye, muhasebe ve bankacılık sayesinde toplum hayatının deveranında diğer güçlerin önüne geçti. (Özel, 2004a, 99-101)

İtalyan şehir devletlerindeki bu gelişmelerden sonra Avrupa medeniyeti Paris-Amsterdam-Londra üçgeniyle şekil alarak yükseldi. Fransa, ticaret kapitalizmi yoluyla milli birliğini kuran, dolayısıyla Avrupa'da millet vasfını kazanan ve dilini tedvin eden ilk ülke oldu. Bu nedenle o dönemde Paris, Avrupa'nın başkenti; diğer yerler ise taşra ve ihmal edilmiş yerlerdi. Daha sonra Hollanda nakliyat faaliyetlerinde ön plana geçerek yükseldi. "Dünyanın hamalları" olarak nitelendirilen Hollandalılar,

2 İsmet Özel, dünya sistemi ile kapitalizmin özdes olmadığını ifade etmekle birlikte bazı yazılarında bu iki kavramı genellikle eş veya yakın anlamlı olarak kullanmıştır. Bkz. (Özel, 2004a, 77); (Özel, 2004b, 83); (Aytekin, 2017, 258-259). Wallerstein de kavramları birbirine yakın anlamda kullanmıștır. "Modern zamanlara kadar kurulmuş olan dünya-ekonomiler ya parçalandılar ya da güç yoluyla dünya-imparatorluklarına dönüștüler. Tarihsel olarak uzun süre yaşamış olan tek dünyaekonomi modern dünya-sistemi olmuştur ve işte bu nedenle modern dünya-sisteminin tanımlayıcı özelliği olarak kapitalist sistem kök tutmuş ve güçlenmiştir." (Wallerstein, 2004, 46). Biz de kavramları aynı anlamda kullanmanın yanlış olmayacağını düşünmekle birlikte Özel’in eserlerinde geçtiği şekliyle ifade etmeyi uygun gördük.

3 Wallerstein de kapitalizmin kâr amacıyla pazarda satış yapan üretici bireyler ya da firmaların varlığından ibaret olmadığını ifade eder. Ona göre bu tür kişiler ya da firmalar dünyanın her yanında ve binlerce yıldan beri var olmuslardır. Ücret için çalışan insanların var olması da yeterli değildir. Ancak sermayenin sonsuz birikimine öncelik tanınması halinde kapitalizmden söz edilebilir. (Wallerstein, 2004, 46) 
Avrupa ile dünyanın diğer bölgeleri arasında birçok kıymetli malı deniz yoluyla taşımanın yanı sıra köle ticaretinde de dünyanın en iyi nakliyatını yapan insanlardı. Bunun sonucunda büyük bir sermaye birikimi sağlandı ve Amsterdam'da senet ve borsa işlemlerine dair menkul piyasası oluştu. Hollanda'nın sömürgelerinin yetersiz kalması nedeniyle sistem Londra'ya taşındı. Britanya, sömürgeleri sayesinde uluslararası ticaretin düzene sokulması ve kârın azamileştirilmesi konusunda elverişli bir irtibat ağı kurdu. (Özel, 2012, 121-122)

Dünya sisteminin hakimiyetinin kalkış noktasında Müslümanların yaşadığı coğrafyayı işgal ettiğini ileri süren Özel'e göre haddi zatında bu topraklar özellikle seçilmemiş; sistem, ayırım göstermeksizin yeryüzünün tüm bölgelerine yayılmıştır. Diğer medeniyetlerin aksine Müslümanların karşı koyabilecek potansiyele sahip olmalarına karşın varlık gösterememeleri sistemin hükümranlığını pekiştirmiştir. 19. yüzyılın başlarından itibaren Müslümanların sistemi zaafa uğratabilecek güçleri olmasına rağmen yöneticiler ve maddi imkânlara sahip olanlar tercihini sistemden yana yaptılar ve sistemin Müslüman toplumlarda daha çok söz sahibi olmaları yönünde hareket ettiler. (Özel, 1989, 80)

Özel'e göre dünya sistemi maddi bir güç olarak belirmesine rağmen gücünü maddi imkânlarından değil, insanlar üzerine saldığı, geleneksel dinlerle paralelliği bulunmayan inanç ve değerler üzerinden almaktadır. Sistem Avrupa'daki doğuşunu Ortaçağ Hristiyanlı̆̆ı karşısında güçlenmesine ve hayatı sekülerleştirmesine borçludur. Yeniçă̆’da özellikle Cizvit tarikatı ve Protestanlığın aldığı biçim nedeniyle Hristiyanlık, dünya sisteminin işleyişini kolaylaştıracak bir ideoloji haline gelmiştir. (1989, 79-80)

Özel, kadim medeniyetlerle kapitalizm arasındaki farka dikkat çekerek modern anlamdaki kapitalizmin biricikliğine ve geleneksel yapıları dönüştürmekteki gücüne vurgu yapmaktadır. Arkaik ve antik medeniyetlerde zengin ve fakir arasında hangi türden ve ölçüde farklar bulunursa bulunsun insan ilişkileri temelde paraya tahvil edilebilen özellikler taşımamıştır. Bu medeniyetlerde, insan ilişkilerinde sermaye dışında kalan değerler baskın olduğu için kapitalizm ortaya çıkabilecek bir zemin bulamadı. Kapitalizm hakim konuma gelinceye kadar insanlar arasında sermayeden daha farklı unsurlar ilişki ve işbölümünü yönlendirmekteydi.

\begin{abstract}
"Ne zaman ki insanlar dünya hayatında güvencenin sermayeden yararlanmakla sağlanacağına inandılar, o zaman önlerinde kapitalizm geri dönülmez bir yol olarak açıldı. Kapitalizm yolunda yürümenin hızı, zengin olsun, fakir olsun herkesin ne yaparsam ne kadar kazanırım hesabıyla yaşaması yüzünden yükseldi. İlerledikçe hesap yapmak, hesap yaptıkça ilerlemek gerekti. Kapitalizm yaşamayı bisiklete binmeye benzetmişti; pedala basmayan düşüyordu.” (Özel, 2004a, 81-82)
\end{abstract}

Kapitalizm, bir kırılmaya yol açarak insan ilişkilerini dönüştürdü. Sermayenin ve buna bağlı ilişkilerin başat olmadığı pre-kapitalist dönemde insan ilişkileri kimlik eksenli bir muhtevaya sahipti. Aynı kandan gelmiş olmak, aynı inanca sahip olmak veya belirli bir mekânı paylaşıyor olmak hem kimliklerde hem de ilişkilerde belirleyici faktörlerdi. (Özel, 1990, 17) Fakat kapitalizm, daha çok kazanmayı ve insan ilişkilerinde kârın maksimizasyonunu insan ilişkilerinde merkeze aldı.

\footnotetext{
"Kapitalizmin sözünü geçirdiği toplumda milliyet, din, ahlâk birer güçlü tayin edici olarak yoktur veya sadece paranın milliyeti, paranın dini ve paranın ahlâkı asıl tayin edici olarak geçerlidir. Toplum artık bir organizmanın gösterdiği tepkilerle harekete geçmez, toplumu harekete geçiren, bir manivelanın mekanizmayı çalıştırma faaliyetidir. Kapitalist toplumda her derecede yöneten ve yönetilen vardır. Öyle ki bir kademedeki yönetici bir başkasına göre yönetilendir, tıpkı bir makinenin her birini harekete geçiren parçaları gibi.” (1990, 18-19)
} 
Dünya sistemi, ancient regime öncesi var olan devletleri de dönüştürdü. İnsanlara değer yargıları, ahlâk ilkeleri ve hayat yorumları veren devlet yapısı çözüldü. Toplumların sahip olduğu değerler farklı olduğu için buna göre farklı devletler ortaya çıkıyordu. Kapitalizmin bu değerleri para veya menfaate indirgemesiyle birlikte kadim devlet ve toplum ilişkisi yani yöneten-yönetilen anlayışı değişime uğradı.

\begin{abstract}
"Modern çağlara, yani kapitalizmin alenen zuhuruna kadar insan toplumlarının, üzerinde anlaşmaya varılmış değer yargıları, kabullenilmiş ahlâk ilkeleri, hayatın yorumu olmaksızın ayakta kalamayacağı biliniyordu. Devlet insanlara değer yargıları, ahlâk ilkeleri, hayat yorumu veriyor; insanların değer yargıları, ahlâk ilkeleri, hayat yorumları bulunduğu için devlet teşkil ediyorlardı. Farklı devletler vardı, çünkü farklı değerler vardı. Kapitalizm bu farklı değerleri teke indirgedi; para veya menfaat. Ĕ̆er insanları bir arada tutan unsur menfaat birliği idiyse, söz konusu menfaatin temin edilebildiği bir toplum devletin örgütleyici, düzenleyici ve giderek denetleyici müdahalesi olmaksızın varlığını devam ettirebilirdi. Kazanç ve kâr elde etme mekanizması toplum hayatını düzenlemede öylesine mutlak bir iktidarı kullandığı düşüncesinde idi ki fazladan bir düzenleyici, devleti kendine ayakbağı sayıyordu." (Özel, 1989, 150)
\end{abstract}

\title{
3.2. Dünya sisteminin işleyişi
}

İsmet Özel'e göre bankacılık, dünya sisteminin iskeletidir.

\begin{abstract}
"Bu iskeleti hem korumak hem de ona hareket, cazibe ve kimlik kazandırmak için birçok 'dış' unsur vardır. Mali iskeletin teknolojisi, medeniyeti, sanatı, iletişim atmosferi vardır. Her şeyden önemlisi kendine mahsus bir 'beyni' vardır dünya sisteminin. Fakat bu beynin çalışabilmesi için iskeletin sağlam olması ön şarttır. Bu yüzden dünya sistemi piyasa ilişkileri dolayısıyla mütedavil sermayenin üstünlüğünü korumayı hayatiyeti için vazgeçilmez önemde sayar. Ne ki mali üstünlükten daha çok önem taşımaya başlar işte o unsur dünya sistemine karşı yönelmiş bir tehdit olarak algılanır.” (Özel, 1990, 98)
\end{abstract}

Dünya sisteminin din karşıtı batıl bir din olduğunu ileri süren Özel, sistemi sadece bir iktisadi mekanizma görerek ona karşı mücadele etmeyi kendi gölgesiyle savaşmaya benzetir. Sistem, kârını artırarak genişlemektedir. Kârın belli ellerden başka ellere nakledilmesi için savaşanlar sistemin ancak daha kârlı olmasına ve etkinliğini artırmasına sebebiyet vermektedirler. Daha becerikli özelliklere sahip olan ve sisteme taze kan pompalayanların faaliyetleri sistemi memnun etmektedir.

"Sistemin iktisadi işleyişine iktisadi güçle müdahale etmek ancak işleyişin kurallarını daha etkin uygulamakla mümkündür ki burada sisteme muhalefet muvafakatla sonuçlanabilir. Banknot, saltanatını muhafaza ettiği sürece herhangi bir İslam ülkesinin para biriminin değer kazanması veya geçerli sayılması bu durumu değiştirmez. Velev ki onun adı ‘'̇slam dinarı’ olsa bile” (Özel, 1989, 8283)

Dünya sisteminin önemli bir özelliği de muhalif hareketleri biçimlendirebilmesi, yön vermesi ve sistem içinde tutabilmesidir. Bunda sistemin rolü olmakla birlikte sistemin değerlerini benimseyen insanların sistem içinde kendilerine bir yer edinme çabalarının önemli etkisi vardır.
"Dünya sistemi insan yığınlarını hegemonya altında tutmakla yetinmiyor, sisteme olan muhalefetin türünü, cinsini ve mikyasını da kendi istekleri doğrultusunda tespit etmek ve giderek kemikleştirmek için elinden geleni de ardına bırakmıyor. Başarıya kavuşmak için bazı teşkilatlar kurup insan yığınlarını tekrar be tekrar şekillendirme çalışması yürütmeye ihtiyacı yok. İnsan yığınları dünya sistemi ağılına girmeyi en 'kârlı' iş kabul ettikleri müddetçe ve tuzaktaki yemi ısırmanın bir zekâ belirtisi olduğu kanaatini taşımaktan vazgeçmedikçe sistemin işi tıkırındadır.” (Özel, 2003, 53)

Kapitalizm, siyaseti, dini, bilimi, sanatı vb. ne varsa pazara sürebileceği nitelik ve nicelikte kısımlara bölerek piyasaya sunmaktadır. Bunu yaparken zorluklarla karşılaşmasına rağmen yine de üstesinden gelebilmekte ve çökme tehlikesini her defasında bertaraf edebilmektedir. Bunun nedeni kapitalizmin Yeniçağda ürettiği sirkülasyona girmeye hazır müşteri ve malların sürekli var olmasıdır. Kapitalizmin 
kendilerine istedikleri her şeyi verebileceğine inanan milyonlarca insan bunalıma girdiği her dönemde yine sistemin imdadına yetişmektedir. (Özel, 2004a, 89-90)

\title{
3.3. Dünya sistemi ve dünya savaşları
}

Her ne kadar İki dünya savaşı öncesinde Napolyon Savaşları ve Kırım harbi vuku bulmuş, neticeleri Avrupa devletleri ve milletlerinin hayatlarını etkilemiş olsa da İsmet Özel'e göre bu dönemde dünya sistemi kemikleşmemiştir. Bu nedenle söz konusu savaşlara "dünya savaşı” denilemez. Ona göre dünya sisteminin kemikleşmesi bakımından iki dünya savaşı çok önemli olgulardır. Birbirinin devamı niteliğinde olan iki dünya savaşının galibi Batı medeniyetinin modern zamanlarda ortaya çıardığı mekanizmalar, özellikle de piyasa mekanizmasıdır. Bu savaşlar sonunda dünya sistemi, Avrupalı ve Kuzey Amerikalı insanları mekanizmalar içinde hapsederek hem hazmetmek hem de korkutarak kabuğuna çekilmek anlamında sindirmiştir. Buna mukabil söz konusu coğrafyalarda yaşayan insanların refah seviyesi yükseltilerek ve güvenceye bağlanarak tatmin edilmeleri sağlanmıştır. (Özel, 1991, 68-70)

Dünya savaşlarının her ikisini de kazanan “dolar”, Faşizmi, Nazizmi ve Japon İmparatorluğunu mağlup etmiştir. Avrupa ve Britanya'nın uyguladığı şekliyle kapitalizm tarihte kalmış, onun yerini kendisinden başkasına söz hakkı tanımayacak kadar güçlü olan Amerikan emperyalizmi almıştır. Totaliter rejimler ezilmiş, Sovyetler ve Çin sindirilmiş ama yerine Amerikan emperyalizmi gelmiştir. (Özel, 2004b, 90-91)

1950'li yılların başlarından 1980'lerin sonuna kadar olan dönemde Üçüncü Dünya Savaşı’nın meydana geldiğini ileri süren Özel'e göre her ne kadar paralellikler arz etse de bu savaş, "Soğuk savaş” adı verilen ve ABD ile SSCB arasında cereyan eden çatışma ve rekabetten farklıdır.

\begin{abstract}
"Programı dünya sistemi tarafından hazırlanmış bir düzensiz ayaklanmalar toplamına üçüncü dünya savaşı demek gerekir. Eski Asya-Afrika koloni bölgelerinde kurulmuş devletlerin sermaye paylaşımında daha büyük bir lokma koparabilmek için giriştikleri mücadele en açık ifadesini 1955’te Bandung konferansıyla ${ }^{4}$ buldu. Savaşa bir başka cepheden Latin Amerika'nın da katıldığını hesaba katarsak, otuz yllık mücadelenin farklı gerilimlerde ve fakat rabıtalı bir dünya savaşı olduğunu anlayabiliriz. Tıpkı iki dünya savaşı gibi üçüncü dünya savaşı da dünya sisteminin çıplak ve kaba maddi çıkarlarıyla milletlerin hayat hakkı arasında cereyan etmiştir. Her üç savaşta da karşı çıkanlar düşmanlarının silahlarıyla dövüşmeye mecbur bırakılmışlar ve bu tuzaktan kurtulamadıkları için her üç dünya savaşını da ‘sistem’ kazanmıştır.” (Özel, 1991, 71)
\end{abstract}

İsmet Özel, dünya sistemi tarafindan yürütülen üç dünya savaşından sonra dördüncü dünya savaşından söz etmektedir. Ona göre "insanı şahsiyet sahibi kılan özellikleri toplum hayatının etkin noktalarından silmeye yönelen" üç dünya savaşı da dünya sistemi tarafından yürütülmüş ve bu savaşlardan sistem galip çlkmıştır. Özel, tam olarak nasıl cereyan edeceğine dair bir açıklama yapmamasına rağmen dördüncü dünya savaşının alanını ve savaş araçlarını Müslümanların belirleyeceğini ileri sürer. Bunun için “dünya sisteminin tuzaklarından salim kalmış bir akıl ve eylem düzeyinde hareket edilmelidir.” Müslümanlara düşen bu görev ancak Müslümanca bir aydınlanmanın en büyük imkân olduğu fark edilerek yerine getirilebilir. (1991, 73-74)

1990'ların başında Doğu Bloku’nun çöküşü de Özel'e göre dünya sisteminin kendini yenilemesinin bir göstergesidir. Ardından kapitalizmin çökeceğini düşünenler büyük bir yanılsama içine düşmüşlerdir.

\footnotetext{
$4 \quad$ Bandung Konferansı: Bağımsızlıklarını yeni kazanmış olan Asya ve Afrika ülkelerinin, dönemin iki süper gücü ABD ve Sovyet Rusya karşısında varlıklarını koruyabilmek için aralarında birlik ve dayanışma sağlamak amacıyla 18-24 Nisan 1955'de Endonezya'nın Bandung șehrinde düzenlenmiștir. 29 Asya ve Afrika ülkesinin katıldı̆̆ı konferansta, iyi niyet ve işbirliğini arttıracak tedbirler, müşterek ekonomik ve sosyal problemler, milli egemenlik, rrkçıllk ve sömürgecilik gibi meseleler ele alınmıştır. Murat $(2018,368)$
} 
“Dünya sisteminin lordları Doğu Avrupa rejimlerini çökertir çökertmez Ortadoğu'da savaş çıkarmakla Batı medeniyetinin geleceğini tartışma alanına getirmeden dünyadaki yeni düzeni (hep yenileşen sistemi) pekiştirme yoluna girdiler. Barışın canavarlığı buradan doğuyor. 'Komunizm çöktü, şimdi sıra kapitalizmde' diyenler de 'Devletçi sosyalizmden vaz geçtik, Doğu Avrupa'da demokrasinin zaferi yaşanıyor' diyenler de dünya sisteminin tuzağına düşmüşlerdir. Dünya sistemi onları bir sonraki aşama için yani Ortadoğu'ya yeni düzen getirme çabaları için birer yan güç olarak elinin altına almıştır.” (1991, 86)

\title{
3.4. Dünya sistemi ve Türkler
}

İsmet Özel, bir yazısında İngiliz tarihçi Lord Acton’un (1834-1902) “Modern tarih Osmanl fethi baskısı altında başlar" sözünü yorumlarken sanat, din, hukuk, bilim ve toplum ilişkilerini düzenleyen kural ve kurumların modernleşmesiyle Osmanlı fetihleri arasında doğrudan bir bağ kurulamayacağını iddia eder. Ona göre Avrupa'daki bütün bu alanlardaki değişimlerle Osmanlı fetihleri arasındaki ilişki ancak dolaylı yoldan olabilir. Avrupa olgusuyla Türk olgusu arasında dolaylı olarak gördüğü ilişkilerin yegâne istisnası kapitalizmdir.

\begin{abstract}
"Osmanlı fethi ile modern tarih arasında kurabileceğimiz yegâne doğrudan bağ Akdeniz havzasında bir yandan kapitalizmin doğmasına imkân veren bir toprak parçası bırakan ve diğer yanda kapitalizmin doğmasına imkân vermeyen büyük bir alanın korunmasını teminata bağlayan bağdır. Türklerin Doğu Avrupa'yı ve Kuzey Afrika'yı zabtetmiş olması kapitalizmi doğurdu. Türkler, Batı Hristiyanlı̆̆ını Avrupa'ya kıstırdıkları, hapsettikleri, sıkıştırdıkları için "milletlerin zenginliği" yeni iktisadi usullerin etkinleştirilmesine bağlanmak zorunda kalmıştır. Türkler Avrupalıları bilinen ve hayatiyeti olan dünyadan yaltttı." (Özel, 2004a, 99)
\end{abstract}

Özel'e göre kapitalizmin dünya ölçeğinde yayılmasında ve günümüze kadar gelebilmesinde ana unsur Fransız İhtilali veya sanayileşme değil, Türklerin 1571 yllındaki İnebahtı yenilgisidir. Kapitalizm, bu savaşla birlikte, yani Türklerin yenilme ihtimalinin belirmesi üzerine kendi varlığını güvence altında hissetmiştir. "Kapitalizm hegemonya kuracak yetkiyi dünya siyasetinin Türk gücünden noksan bırakılışından aldı. Dünya Sistemi müdevvir bir sistem olabilmek için Türklerin sözünün geçmediği bir atmosfere muhtaçtı." (2004a, 99-102)

Kapitalizmin aşamaları esnasında Türklerin sisteme entegre olmadan ayakta kalabilme başarısını gösterdiğini ifade eden Özel, Türklerin bu vasfının günümüzde kapitalizmden çıkış yolu arayanlar için önemli dersler barındırdığını ileri sürmektedir. Türkler, anti-kapitalist bir hayat tarzını başını dik tutarak sürdürmeyi başarabilmiş yegâne millettir. Türklerin haricinde anti-kapitalist konumda bulunanlar varsa onların bu konumu ancak müstemlekeleşme olmuştur. (Özel, 2004b, 83-84)

Özel'e göre kapitalizmin doğuşu doğrudan doğruya Türklerle ilgili olduğu gibi, akibeti, daha doğrusu son bulması da yine doğrudan Türklerle ilgili olacaktır. Özel, şimdilik buna dair ciddi bir emare görünmediğini söylemekle birlikte (Özel, 2012, 325) dünyanın (dünya sisteminden/kapitalizmden) kurtuluşunun Türkiye'nin kurtuluşuna bağlı olduğuna inanmaktadır. Aksi durumda herhangi bir kurtuluş yolu yoktur. "Eğer Türk günümüz şartlarında kapitalizmi hasım kabul etme seciyesini gösterebilirse dünya işlerinin seyri tepeden tırnağa değişir, farklılaşır. Neden? Çünkü Türkiye, Vietnam veya Belçika olmadığı gibi, Afganistan veya Irak da değildir.” (Özel, 2003, 83)

\footnotetext{
"Kapitalizm hegemonya kuracak yetkiyi dünya siyasetinin Türk gücünden noksan bırakılışından aldı. Dünya Sistemi müdevvir (mütemadiyen işleyen) bir sistem olabilmek için Türklerin sözünün geçmediği bir atmosfere muhtaçtı. Kapitalizm hala aynı ihtiyaç içinde kıvranıyor. Kapitalizmin insan varlığına hor bakan tasallutundan Türkiye'nin kurtulma gücü kalmadıysa dünyanın bu tasalluttan kurtulabileceği konusunu ciddiye almak abesle iştigaldir.” (Özel, 2004a, 101-102)
} 
Yeryüzünü ifsat eden kapitalizmden kurtulmak isteniyorsa bunun yolunun sistemin sslahından geçmediği gibi kapitalist ilişkilerin dönüşüme uğraması anlamına gelen sosyalizmden de geçmediğini düşünen Özel, bu anlamda Türkiye’ye hususi bir rol biçmektedir. Çünkü Türkiye, "geçmişi feodal ilişkilerle yoğrulmayıp modern dünyada (de facto) varlık sahibi olmayı başarabilen tek ülkedir.” Türkiye, kapitalist gelişmenin vuku bulduğu coğrafyayla sınır olmasına rağmen kapitalizmin küreselleşme aşamasına kadar kendisine mahsus bir iktisadi işleyişi korumuştur. "Türkiye, diğer bütün 'Batılıolmayan' ülkelerden gerek kolonyalizme konu olmayışı bakımından ve gerekse 'Batı' akıl düzeninin yeniden şekil verme çabaları karşısında tarihi konumundan devşirdiği bağışıklıkla hareket etmesi bakımından ayrılır.” Özel bu bağlamda son dört yüz yll boyunca var olan iki tip akıldan söz eder. Bunlardan birincisi kapitalizmin dünyayı şekillendirdiği Amerikan aklıdır. Diğer bir deyişle kapitalizm yerküreyi ve hangi ulustan olursa olsun insanları Amerikan standartlarına uygun hale getirmiştir. Buna mukabil karşı tarafta anti-kapitalist özelliklere sahip, en bariz vasfı Müslümanlık olan ve oluşumunu dünya sistemi içinde gerçekleştirmemiş bulunan Türklük vardır. (Özel, 2002, 93)

İsmet Özel'in hususiyetle vurguladığı bir konu da Türkiye'nin millet olma vasfıdır. Türkler, bu vasıflarını (Avrupa ve sömürgeleri de dahil olmak üzere) diğer milletler gibi modernleşmenin bir ürünü olmasına ve kapitalizme katkı yapmaya borçlu değildir. (Özel, 2002, 95) Kapitalizm Türkler hariç diğer milletleri bünyesinde sindirebilmiştir. Türk idaresi ise hiçbir zaman dünya sisteminin merkezleri veya sermaye tarafından tayin edilmemiştir. "Bunun sebebi Türk idaresinin teşkil ettiği kendine mahsus bir merkezin toplum hayatını çekip çevirecek maharet ve ehliyet gösterebilmesidir.” (Özel, 2002, 103) Özel, Türklüğün bu özelliklerinin tarihte mevcut olmakla birlikte günümüzde ete-kemiğe bürünmediğini ve ancak bir imkân olarak var olduğunu ileri sürmektedir. Böylece ütopya peşinde olmadığını ifade etmekte fakat bu imkânı bir ideal ortaya koymaktadır.

“Türkiye’nin yerküre üzerindeki özel anlamı 'kökü mazide olan ati’ sebebiyledir. Dünyada varlığı yüzünden gelecek vadeden yegâne ülkenin Türkiye olduğunu söyleme durumundayı. Türklügün dünyada başat duruma geçeceğinin hayalini kurmuyorum. Dünyanın rezil ve sefil şartlarını alt etmede Türklüğün ve Türkleşmenin bir imkân sunduğunu savunuyorum, o kadar.” $(2002,92)$

\subsection{Cumhuriyet dönemi ve sonrasında Türkiye-dünya sistemi ilişkileri}

İsmet Özel'e göre Lale Devri’nden itibaren Türk kültürü ile Avrupa medeniyeti arasında mahiyet değil de sadece derece farkı olduğuna dair bir zihin karışıklı̆̆ mevcuttur. Buna binaen birinin diğerine üstünlük sağlayacağı düşünülmüş ve bu yaklaşım gelişmişlik-az gelişmişlik literatürünü doğurmuştur. Bunun sonucunda Dünya Sistemi’nin Türkiye Cumhuriyeti’ne uygun gördüğü konum hem yönetenler hem de yönetilenler tarafından içselleştirilmiştir. (Özel, 2003, 77)

Özel, Türkiye Cumhuriyeti’nin, Birinci Dünya Savaşı’nın galipleriyle yapılan pazarlıklar, uzlaşmalar ve çatışmalar sonucunda kurulabildiğini ileri sürer. Bu bağlamda Türkiye İngilizlerle pazarlık yapmış, Fransızlar ve İtalyanlarla uzlaşmış, Yunanlılarla savaşmıştır. Kuruluştaki bu olaylar Türkiye'nin dünya milletleri arasındaki yerini belirlemiştir. Bu yer, Türkiye'ye Dünya Sistemi’nin işleyişine zarar vermeyeceği, sistem tarafindan kendisine tahsis edilen alandı. Bunun sonucunda Türkiye, dünyada cereyan eden olaylar karşısında etkiye açık bir pozisyonda kaldı. "Bugün sürekli olarak dünya ahvalinin değişmesine göre dalgalanmak zorunda kalışımızın ve bir türlü kendi küçük işlerimizi bile üzerlerine büyük tasarıların gölgesi düşmeksizin halledemeyişimizin sebebi budur." (Özel, 1995, 83)

Türkiye Cumhuriyeti kurulurken Bolşevik, Pantürkist ve Panislamist bir ülke olmayacağı şartları koşulduğunu iddia eden İsmet Özel'e göre bu üç politikadan birine mensup olunması Türkiye'nin dünya 
politik sahnesinde aktif bir şekilde yer alması anlamına gelecekti. Bu nedenle dünya sistemi, riske girmek istemediği için Cumhuriyet Türkiye'sine bu üç akımdan uzakta kalınmasını şart koştu. Cumhuriyetin kurulduğu dönemde dünya sisteminin politikası, yeni devletin sistemin işleyişine zarar vermemesi ve imparatorluk döneminin büyük iddialarıyla ilgili faaliyetlere girmemesiydi. Buna mukabil sistemin kendisini oluşturan mantık içinde Türkiye'nin milli pazarı ve milli ideolojisi olan bir birim oluşturabilmesine izin verilebiliyordu. (Özel, 1997, 309-310)

Dünya sistemi her ne kadar Türkiye'yi 1908 İkinci Meşrutiyet Devrimi sayesinde ekonomik olarak kendisine entegre etmişse de bunun politik olarak da gerçekleşmesi Birinci Dünya Savaşıyla oldu. Savaş sonunda Rus Çarı, Alman Kayseri, Avusturya Macaristan İmparatoru ve İslam Halifesi ortadan kalkmıştı. Söz konusu imparatorluklar parçalanması ve yutulması çok kolay olan birimler olarak "milli pazar” formunda çevre ülkeler haline getirildiler.

Cumhuriyet, Özel'e göre Türklere bir dünya gücü olmaksızın dünyanın kâbustan kurutulma ümidi durumuna yükseltme imkânını bahşetmişti. Cumhuriyetten hemen sonra Türkiye yüzyıllardır geliştirdiği iktisat modelini 20. yüzylla uyarlayarak canlandırmak ve kapitalist olmayan bir iç "milli pazar” oluşturma imkânına sahip idiyse de bu imkân heba edilmiştir. Çünkü Cumhuriyet dönemi yöneticileri toplumun problemlerini halletmede en güçlü kapitalist ülkelerin işleyiş tarzını model olarak kabul etmek yerine dünya sisteminin metropolüne kafa tutan siyasi eğilimlerin modellerini örnek aldı.

\begin{abstract}
"Bu nedenle İki dünya savaşı arasında Türkiye, Sovyet Sosyalizminin iştirakçi tutumundan, İtalyan Faşizminin korportatif uygulamasından ve Alman Nasyonal Sosyalizminin rehberlik ilkesinden etkilendi. Yeni örgütlenmesini bu rejimlerden ödünç aldığı zihniyetle, bu zihniyetin tatbikatıyla gerçekleştirdi. Dünya sistemi kendine kafa tutan siyasi rejimlerin süreç içinde ve sırasıyla hakkından geldi. Ayazda kalıp ayakta kalabilmek için dünya sistemine ihtiyacı her gün biraz daha azgınlaşan Türkiye Cumhuriyeti oldu” (Özel, 2002, 83)
\end{abstract}

İkinci imkân Türkiye'nin Osmanlı Devleti'nden tevarüs edebileceği merkeziyetçi karakterdi. "Merkeziyetçilik Türkiye'de toplumun yardıma ihtiyaç duyan kısmına ve kesimine destek verir ve ömrünü onların desteğiyle uzatır durumdaydı.” Osmanlı Devleti'nde merkeziyetçilik devletin işleyişine ilişkin teknik bir özelliğe indirgenebilmesine rağmen Cumhuriyet dönemi daha çok merkeziyetçiliğin baskıcı karaktere bürünmesini tercih etmiştir. $(2002,83)$

Özel'e göre günümüz Türkiye'sinin belirlenmesinde Birinci Dünya Savaşı'ndan mağlup çlkması sonucunda karar alma yetkisini kaybetmesi önemli bir unsur olmuştur. Türkiye karar alma yetkisini elinden kaçırmış ve sistemin her evresindeki dönüşümlerden etkilenir hale gelmiştir. Diğer bir belirleyici dönem İkinci Dünya savaşı sonrasıdır. Türkiye savaş sonrasında çok partili hayata geçmiş fakat siyasi gücün belirlenmesinde millete çok sınırlı ve denetim altında söz hakkı tanınmıştır. Bu şartlar altında millet, devletten dünya milletleri arasında kendisine mahsus ve yalnızca kendisinin karar sahibi olduğu bir yer talep etmekle birlikte bu talepler, 1960, 1971 ve 1980 yllarındaki askeri müdahalelerle reddedilmiştir. (Özel, 1995, 143)

Dünya sisteminin dünyada uyguladığı operasyonların Türkiye'de yaşananlarla birbirlerini bütünler özellikte olduğunu ileri süren İsmet Özel'e göre 12 Eylül 1980 darbesiyle başlayan süreçte ülke yönetimi ile sistem ilişkileri dolaylı olmaktan çıkarak peşin bir bağlllık ilişkisine dönüşmüştür. "Türkiye’nin 12 Eylül 1980 sonrasında geçirdiği yapısal değişiklik, sistemin kasıtlı olarak kendinden uzak tuttuğu Sovyetler Birliği ve Doğu Avrupa'da uygulanan yapısal değişiklikle aynı amaca matuftur. Sosyal hayatın düzenlenmesini IMF ve Dünya Bankası gibi büyük finans kuruluşlarınca alınan kararların denetimine birakmak.” (Özel, 1991, 160-161) 


\title{
3.6. Dünya sisteminin geleceği açısından taşıdığı riskler
}

Dünya sisteminin çökebileceğine dair kanaat İsmet Özel'e göre sadece sisteme muhalif olanlar değil aynı zamanda sistemin savunucuları tarafından da paylaşılmaktadır. Sistem, sermayenin hakimiyetinden doğduğu için bu hakimiyetin ortadan kalkması durumunda kapitalizm doğal olarak sona erecektir. Demokratlar ve sosyalistler birikmiş ve belirli ellerde toplanmış olan sermayeye karşı olmayıp sadece sermayenin ıslahına odaklanmaktadırlar. Öte yandan sermayenin kamuya bölüştürülmesi de söz konusu çevreleri endişelendirmektedir. Böyle bir bölüşüm karar mekanizmalarının başında kimse kalmaması, kapitalizmin ve daha ötesi demokrat ve sosyalist hümanizmanın son bulması anlamına gelecektir.

\begin{abstract}
“Çünkü sermaye gücündeki eşitlik herkesin üzerinden dünya sisteminin kurallarına uyma baskısını kaldıracaktır. Demokratlar ve sosyalistler sermaye hareketlerini yönlendirecek bir azınlığın iş başında bulunmasındaki işlevselliği kabullenerek siyaset yaparlar. Bu siyaset insanlığın düçar olduğu belanın bir mali mahrumiyet belası olduğu görüşünü aşamayacak bir siyasettir. Demek ki demokratlara ve sosyalistlere göre karnı tok, sırtı pek insanların yaşadığı toplum belayı atlatmış olan toplumdur. Ĕ̆er dünya sisteminin metropol alanlarında karnı tok, sırtı pek insanların 'ezici çoğunluğu' teşkil ettiği inkâr edilmez bir gerçekse, neden sermaye sahiplerinin demokrat ve sosyalistlere dudak büktükleri kendiliğinden açıklanmış olur.” (Özel, 2004a, 90-91)
\end{abstract}

Özel'e göre kapitalizmi ortadan kaldıracak olan çelişki emek-sermaye çelişkisi olamaz. Aksini düşünenler, yani kapitalizmin çöküşünü emek-sermaye çelişkisinde göstermek isteyenler çıarlarına uygun düştüğü için kapitalizmi gerekli bir evrimin ve kaçınılmaz gelişimin bir sonucu olarak görmektedirler. Zira, böyle algılanması durumunda kapitalizmin neden olduğu problemlerin çaresinin yine kapitalizmi doğuran şartlar dairesinde aranıp bulunabileceği propagandası yapılacak ve kapitalizmin dışında farklı açılımlar arayanların önünde bu algı engel teşkil edecektir. Kapitalist örgütlenmeler ve buna dayalı insan ilişkileri asli ve gerçek olarak algılanacak; bunun dışında kalan insan ilişkileri ise arızi, arızalı ve hayali hayatlar olarak damgalanacaktır. (Özel, 2004a, 98-99) Aslında 400 ylldan beri kapitalizme şekil veren emek-sermaye çiftinin her ikisi de birbirini döllemekte, sonuçta kapitalizme hayatiyet veren tüketim kültürü doğmaktadır. (Özel, 2004a, 89) Bu açıdan emek-sermaye ikilisinden birinin, diğerinin çelişiği olduğunu kabul etmek mümkün değildir. Kapitalizm ile komünizm arasında uyuşmazlık olduğuna dair iddia Özel için epistemik şiddet olarak değerlendirilebilecek bir şartlandırmadır. Böylece dünyanın mevcut durumda olduğu gibi algılanması neredeyse imkânsız hale gelmektedir. (Özel, 2004b, 65)

İsmet Özel, dünya sisteminin kontrolünden çıkabilmenin ve alternatif güç olabilmenin yolunun farklı değerler sistemi içinde bir dünya kurabilmekten geçtiğine inanır. Çarlık Rusyası, Sovyetler Birliği'nden önce Batı'dakinden farklı bir cazibe merkezi oluşturma yönünde önemli adımlar atmıştı. Petro'dan Lenin'e kadar olan dönemde Rusya'da hem alanlarında önemli işler başarmış, hem de Avrupa tarafından da takip edilebilir çı̆̆ır açmış insanlar zümresi mevcuttu. Bu durum dünya sistemi için ciddi bir tehdit oluşturuyordu. Fakat Rusya'nın sahip olduğu imkân Sovyetlerin kurulmasından sonra heba edilmiştir. Benzer şeyler Türkiye'de de vuku bulmuştur.. Bu bakımdan Türkiye'de Cumhuriyetin kurulması Rusya'da Sovyetlerin kurulmasıyla paralellik arz etmiştir. (Özel, 1997, 308-309)

Dünya sisteminin varlı̆̆ına ve devamına karşı bazı risklerin mevcudiyetine dikkat çeken Özel'e göre bu risklerden birincisi Avrupa'yı çevreleyen Müslüman ülkelerin birinde yaşanabilecek olan bir dönüşümün kıta Avrupa'sını da dönüştürebilme ihtimalidir. İkincisi ise İslam dininin bizatihi kendisinin dünya sisteminin işleyişine karşı olması hasebiyle Müslümanların potansiyel olarak bu imkânı taşımasıdır. Her ne kadar Müslüman ülkeler "çevre" konumunda ise de bu ülkelerin aynı 
zamanda Avrupa'yı çevrelediği ve kuşattığı gerçeği unutulmamalıdır. Yani Müslüman ülkelerde meydana gelebilecek sistem aleyhtarı değişmeler Avrupa'yı en azından iktisadi olarak etkileme imkânına sahiptir. Dünya sisteminin Avrupa'yı çevreleyen ülkelerdeki hareketler karşısında çok hassas olmasının nedeni de budur.

Özel'e göre (Avrupa'yı da derinden ilgilendirdiği şekliyle) İbrahimi gelenek, Müslüman ülkelerde baskıya maruz kalmasına ve seküler akımların tasallutuna uğramasına rağmen bu geleneği yaşayan insanların etkinliği sayesinde canlılığını korumaktadır. Avrupa’yı çevreleyen ülkelerden birinde geleneğin maruz kaldığı baskıyı üzerinden atmasıyla ortaya çıabilecek bir oluşumun dünya sistemi karşısında alternatifler üretebilen bir Avrupa'yı doğurma ihtimali sistem açısından göz önüne alınması gereken bir tehdittir. "Dünya sisteminin Avrupa kıtasında içten çöküşü bu kıta üstünde yaşayan insanların Asyalılar veya Müslümanlar tarafından istilaya uğramaları suretiyle değil, kendi değerlerini yeniden keşfetmeleri sonucunda gerçekleşebilir.” Dünya sistemi, Avrupa'daki milli kimlik arayışlarına Müslüman ülkelerdekinden bile daha da fazla hassasiyet göstermekte ve Avrupa'daki basını daha yoğun bir denetim altında bulundurulmaktadır. Sistem mutlakiyetçi gücünü, geleneği ortadan kaldırarak elde ettiği için bu gücü yine ancak geleneğin hayatiyet bulduğu yer ve zamanda kaybedecektir. Özel'e göre geleneğin yaşandığı yer Çin, Afrika ve Tibet gibi bölgeler değil Müslüman ülkelerin yaşadığı coğrafyalardır. Dünya sistemi gücünü Müslüman ülkelerde kaybettiğinin ve metropol ülkelerdeki kurtuluş eğilimlerinin Müslüman ülkelerdekilerle sıkı sıkıya irtibatlı olduğunun bilincindedir (Özel, 1990, 65-67).

İsmet Özel, her ne kadar Avrupa'da sisteme alternatif olabilecek dünya görüşlerinin belirme ihtimalini göz önünde bulundursa da sisteme meydan okuyabilecek ve onun hükümranlığını sona erdirebilecek yegâne güç olarak İslam’ı görmektedir. Dünya sistemi gerek Müslümanların, gerek diğer din ve medeniyetlerin değerlerini yıkmış ve gelişme imkânlarını ellerinden almıştır. Buna binaen Özel'e göre Müslümanların dışındaki diğer insanlar sistemin karşısında yer alsa bile sistem karşıtı bir güç oluşturmayacaklardır. Bunun nedenini temelde dünya sisteminin kendi dini vasıflarını gözden uzak tutmaya çalışan bir batıl din oluşunda aramak gerekir.

\begin{abstract}
"Müslümanlık dışında kalan bütün diğer dünya görüşleri ve düşünce sistemleri ise ya butlana uğrayış bakımından dünya sisteminin asli özelliğiyle bir ortaklık içindedirler yahut kendilerine dinamizm sağlayacak olan otantik vasıflarını kaybetmişlerdir. Sadece Müslümanlıktır ki temel değerler bakımından dünya sistemiyle iştirak halinde değildir ve bütün ehlileştirme çabalarına rağmen dinamizmini koruyan otantik hayat gücüne sahiptir" (Özel, 1989, 82).
\end{abstract}

Bu nedenle Müslümanların yanısıra Hristiyanlar ve diğer geleneksel kültürler de sistem tarafindan tahrip edilmiş olmasına rağmen İsmet Özel, sistem karşıtı olma özelliği ve zorunluluğunu Müslümanlara hasretmektedir. Aslında Özel'e göre Müslümanların sistem karşıtı olma özelliği pek gerçekçi görünmemektedir. Çünkü dünya sistemi meselesi Müslüman okur-yazarların ve onların takipçilerinin gündemlerinin ilk sırasında yer almamaktadır. Ayrıca Müslümanlar sistem karşıtı bir program ortaya koyamamıştır. Diğer nedenler ise Müslümanların ne kendi ülkelerinde ne de uluslararası düzeyde ortak bir dili konuşmaması ve kendi haklarının savunulması temelinde asgari anlaşma şartlarından yoksunluğudur. Buradan çıkan sonuç, Müslümanlar arasında, dünya sistemi karşıtlığında neşvü nema bulacak, tebellür edecek bir zeminin olmamasıdır. Söz konusu bütün olumsuzluklara rağmen İsmet Özel, kendinde mündemiç özellikleriyle İslam'ın dünya sistemi karşısında imkân açısından bir güç olarak mevcudiyetine atıf yapmaktadır. Mesele Müslümanların bu imkânı değerlendirebilecek donanımlara sahip olup olmamasıdır. 
"Bu olumsuzluklara rağmen dünya sisteminin karşıtlığı yine Müslümanların omuzlarında duruyor. Çünkü küfr sistemi karşısında oluş Müslümanların halihazırdaki durumlarıyla mukayyed değil, Müslümanlığın, İslam dininin mahsus değerleri Müslümanları ister istemez dünya sisteminin karşısına yerleştiriyor. Müslümanlar dinlerine bağlılıklarını artırdıkça dünya sistemi karşısında zıtlaşmayı artıracaklar ve dünya sistemi ile bağlarını güçlendirdikçe de dinlerinden sapmayı kabullenecekler.” $(1989,82)$

\section{Sonuç ve değerlendirme}

Adına dünya sistemi veya kapitalizm denilen ve modern dünyaya hükümran olan ekonomik düzenin İsmet Özel’in düşünce ve yazın dünyasında çok önemli bir yeri vardır. Özel, eserlerinde sıklıkla dünya sistemini konu edinmiş; sistemin zuhurunu, yayılmasını ve günümüzde aldığı şekil ve muhtevasını ortaya koymaya gayret etmiştir. Dünya sistemi karşısında Türkiye'yi ve Türklere mahsus olduğunu düşündüğü değerleri ortaya koymaya çalışması bu açıdan ayrıca önem taşımaktadır.

Özel'e göre dünya sistemi sadece Müslüman coğrafya için değil aynı zamanda sistemin içinde doğup geliştiği Avrupa'da ve bunun dışında tüm dünyada, geçmişte benzeri görülmemiş bir yapı oluşturmuştur. Bu yapı nüvelerini 14. yüzyılda İtalyan şehir devletlerinde oluşturmuş, daha sonra kuzeye yönelerek Amsterdam-Paris-Londra mihverinde yayılma göstermiştir. Sistem, yerküredeki tüm geleneksel yapıları, buna bağlı olarak kimlikleri, aidiyetleri ve toplum-devlet yapılarını dönüştürmüş; temel belirleyici unsur olarak sermayeyi ve buna bağlı ilişkileri ikame etmiştir. Tarihte bu derecede kırılmaya neden olan hakim sistemi İsmet Özel "batıl bir din" olarak nitelendirmektedir. Bu nedenle salt iktisadi açıdan yaklaşmakla sisteminin anlaşılamayacağını ileri sürer.

Türklerle Avrupalıların tüm etkileşimini dolaylı olarak yorumlayan fakat sadece kapitalizmin zuhuru konusunda doğrudan bir etkileşim yaşandığını ileri süren Özel'e göre dünya sistemi veya kapitalizm, Türklerin fetihlerle Avrupa'yı kuşatması ve hapsetmesiyle Avrupa'nın karşılaş̧ı̆̆ı zorluklar neticesinde alternatif bir iktisadi hayat ve işleyiş olarak ortaya çlkmıştır. Uzun yıllar bir yanda kapitalizm, diğer yanda ise kapitalist hayat tarzına yabancı, hatta anti-kapitalist özelliklere sahip olan Türklerin yönetimi olmak üzere iki farklı dünya ve bu dünyalara ait değerler yan yana yaşamıştır.

Dünya sistemi, girdiği tüm savaşlardan galip çlkmış, her defasında tazelenerek gücünü pekiştirmiştir. İsmet Özel'e göre her ne kadar sistem, askeri, siyasi ve mali olarak güçlü bir yapıya sahip olsa da vurgulanması gereken önemli husus sistemin işleyişidir. Bankacılığın, iskeletini oluşturduğu sistem bu iskeleti korumak ve ona hareket, cazibe ve kimlik kazandırmak için birçok unsuru kullanmaktadır. Fakat buna rağmen dünya sistemi asıl gücünü insanların, sistemin esasını oluşturan sermayeyi ve buna bağlı ilişkileri esas kabul ederek bu ilişkilere gönüllü olarak katılmasından almaktadır.

İsmet Özel, sistemin tüm gücüne rağmen yine de bazı riskleri barındırdığını düşünmektedir. Bunlardan biri sistemin içinden zuhur ettiği önemli bir metropol bölge olan Avrupa'nın çevre ülkelerini teşkil eden Müslümanlar tarafından kuşatılmış olmasıdır. Ona göre çevrede meydana gelebilecek sistem aleyhtarı hareketlerin Avrupa'yı etkilemesi ve dönüşüme uğratabilmesi ihtimal dahilindedir.

Dünya sistemi varlığını ve gücünün pekişmesini, geleneksel dünyanın değerlerini boşaltmasına ve kendisine gittikçe genişleyen alanlar açmasına borçludur. Bu nedenle sistemin zafiyete uğratılması, içini boşalttığı dünya geleneklerinin tekrar bu alanı kazanmasıyla mümkün olabilir. Özel, Müslümanlığın dışındaki diğer dinler ve dünya görüşlerinin de sistem tarafından tahrip edilmiş olmalarına rağmen ya asli özellikleri itibarıyla sistemle ortaklık içinde oldukları ya da kendilerine dinamizm sağlayacak olan otantik olma özelliklerini kaybettikleri için sistemi ortadan kaldırabilecek vasıflara sahip olmadıklarını 
ileri sürmektedir. Öte yandan Özel, mevcut durumdaki Müslümanların dünya sistemi meselesini birinci problem olarak görmediklerini, aralarında ortak bir dil ve anlaşma zemini olmadığını ve sistem karşıtı herhangi bir programları bulunmadığını ifade etmektedir. Fakat buna rağmen yine de dünya sistemi karşıtlığını Müslümanların sorumluluğuna yüklemektedir. Çünkü ona göre sistem karşısında oluş Müslümanların mevcut durumlarıyla mukayyet değildir. İslam dininin kendisine has değerleri Müslümanları ister istemez dünya sistemi karşıtlı̆ında konumlandırmaktadır. Bu nedenle İslam’ın bir imkân olarak sunduğu değerlere hayatiyet kazandırmak Müslümanların elindedir.

Özel, dünya sisteminin karşısında önemli bir yerde konumlandırdığı Türklerin sistem için çok ciddi bir tehdit unsuru olduğunu ifade etmektedir. Özel’i bu şekilde düşünmeye sevk eden etkenler, Türklüğün ve Türklerin tarihte kapitalizmden farklı ve kendine mahsus bir yönetim biçimine sahip olması, geçmişte koloni olmaması, Türklerin millet vasfı ve varlı̆̆ını dünya sistemine borçlu olmamasıdır. Özel, bu özellikleriyle Türklerin, dünya sisteminin tüm baskılarına rağmen yine de sisteme karşı bir etki alanı oluşturarak kapitalizmden farklı bir ekonomik sistem kurabileceğine inanmaktadır. Haddi zatında Türklük Özel'e göre halihazırda güçlü bir emare göstermemekle birlikte geçmişte bunu başarabilmiş olmasıyla gelecekte de bir imkân olarak bu özelliğini potansiyel olarak muhafaza etmektedir.

\section{Kaynakça}

Aytekin, A. (2017). İsmet Özel Versus Dünya Sistemi. Ankara : Gece.

Murat, T. (2018). Bandung Konferansı ve Türkiye, Firat Üniversitesi Sosyal Bilimler Dergisi, Cilt: 28, Sayl: 2, 363-379.

Oktik, N ; Kokalan, F. (2001-02), Immanuel Wallerstein; Tarihsel Kapitalizmin Analizi ve Dünya Sistemi, Doğu Batı, Yll:4, Sayı:17, ss. 121-133.

Özel, İ. (1989). Cuma Mektupları 1 : İstanbul : Çıdam.

Özel, İ. (1990). Cuma Mektupları III : İstanbul : Çıdam.

Özel, İ. (1991). Cuma Mektupları IV : İstanbul : Çıdam.

Özel, İ. (1995). Ve'l-Asr. İstanbul : Şûle.

Özel, İ. (1997). Sorulunca Söylenen. İstanbul : Şûle.

Özel, İ. (2002). Cuma Mektupları-7. İstanbul : Şûle.

Özel, İ. (2003). Cuma Mektuplarn 10. İstanbul :Şûle.

Özel, İ. (2003). Cuma Mektupları-9. İstanbul : Şûle.

Özel, İ. (2004a). Henry Sen Neden Buradasın-1. İstanbul : Şûle.

Özel, İ. (2004b). Henry Sen Neden Buradasın-2.İstanbul : Şûle.

Özel, İ. (2012). Bir Akşam Gezintisi Değil Bir İstiklal Yürüyüşü. İstanbul : TiYYO.

Terence K. H-Immanuel W. (1999). Geçiş Çağı (Çev. Ersoy, N. ; Abadoğlu, E. ; Akalın, A. ; Kaya, Y.). İstanbul : Avesta.

Wallerstein, I. (1993). Jeopolitik ve Jeokültür (Çev. Özel, M.). İstanbul : İz.

Wallerstein, I. (1998). Liberalizmden Sonra (Çev. Öz, E.), İstanbul, Metis.

Wallerstein, I. (2003). Amerikan Gücünün Gerileyişi (Çev. Birkan, T.). İstanbul : Metis.

Wallerstein, I. (2004). Dünya-Sistemleri Analizi Bir Giriş. (Çev. Ersoy, N.; Abadoğlu, E.). İstanbul: Aram.

Wallerstein, I. (2006). Tarihsel Kapitalizm (Çev. Alpay, N.). İstanbul : Metis.

Wallerstein, I. vd. (1984). Genel Bunalımın Dinamikleri (Çev. Akar, F.). İstanbul : Belge. 